\title{
Post-discharge surveillance of surgical site infections in teaching hospitals in Brazil
}

\author{
Vigilância pós-alta hospitalar das infecções do sítio cirúrgico \\ em hospitais universitários do Brasil \\ Vigilancia post alta hospitalaria de las infecciones del sitio \\ quirúrgico en hospitales universitarios de Brasil
}

How to cite this article:

Pagamisse AF, Tanner J, Poveda VB. Post-discharge surveillance of surgical site infections in teaching hospitals in Brazil. Rev Esc Enferm USP. 2020;54:e03542. DOI: http://dx.doi.org/10.1590/S1980-220X2018038203542

Amandha Fernandes Pagamisse ${ }^{1}$

Judith Tanner ${ }^{2}$

Vanessa de Brito Poveda ${ }^{1}$

${ }^{1}$ Universidade de São Paulo, Escola de Enfermagem, São Paulo, SP, Brazil.

${ }^{2}$ University of Nottingham, School of Nursing, Nottingham, United Kingdom.
Corresponding author:

Vanessa de Brito Poveda

Av. Dr. Enéas de Carvalho Aguiar, 419

CEP 05403-000 - São Paulo, SP, Brazil

vbpoveda@usp.br

\begin{abstract}
Objective: Understanding the reality of surgical site infections post-discharge surveillance in Brazilian teaching hospitals. Method: A cross-sectional study conducted by sending an online questionnaire to nurses from the Hospital Infection Control Committee of Brazilian teaching hospitals registered in the National Registry of Health Establishments. Results: Of the 193 teaching hospitals in Brazil, eight declined to take part as they did not conduct post-discharge surveillance and 36 did not respond. Twenty five of the remaining 149 hospitals provided detailed responses and 96\% of responding institutions performed surgical site infection surveillance during hospitalization; active search $(29.3 \%)$ was the main method, while $84 \%$ reported performing post-discharge surveillance mainly by telephone (42.8\%). Both surveillance actions have nurses as the main responsible professionals. Conclusion: Nurses play a prominent role in surgical site infection identification/screening actions, and active search during hospitalization allied with post-discharge surveillance by telephone were the preferred methods.
\end{abstract}

\section{DESCRIPTORS}

Surgical Wound Infection; Patient Discharge; Surveillance; Nursing Care; Hospitals, Teaching. 


\section{INTRODUCTION}

Damage associated with health care-associated infections (HAI) has been documented, especially during patient hospitalization. However, with shorter hospitalizations, surgical site infections (SSI) frequently occur in the post-discharge period.

Thus, in addition to preventing emotional and physical damage, active surveillance of possible SSI cases also reduces treatment and readmission costs. For example, a previous study has shown in a retrospective analysis that $10 \%$ of 3,663 patients undergoing general surgery developed SSIs, of which $48 \%$ of the cases were detected after hospital discharge, and a further $54 \%$ of these were readmitted ${ }^{(1)}$.

Similarly, another investigation found that among 59,273 patients undergoing elective surgeries, $55,7 \%$ of SSI were diagnosed after discharge and were associated with a higher rate of readmission ${ }^{(2)}$.

Therefore, active follow up for cases during hospitalization associated with post-discharge surveillance (PDS) becomes fundamental. In order to do so, several methods have been employed for performing PDS such as by telephone, by letter/e-mail and searching for pharmaceutical records of antibiotics use ${ }^{(3)}$.

Surveillance related to SSI allows us to review work processes, improving the quality of care offered to patients and reducing the cost of health care and the morbidity generated by the consequences of infections to patients' health.

Thus, unveiling the surveillance methods employed in Brazil among teaching hospitals can give us indications of the national reality regarding this subject. Therefore, the study's aims were: to understand the reality of surgical site infections post-discharge surveillance in Brazilian teaching hospitals and to identify PDS methods used and the professionals responsible for surveying and evaluating information on PDS.

\section{METHOD}

\section{Design OF STUdy}

This was a cross-sectional study.

\section{Population}

The study was carried out by sending an online questionnaire to the e-mail addresses of nurses from the Hospital Infection Control Committee (CCIH-Comissão de Controle de Infecção Hospitalar) of Brazilian teaching hospitals, registered in the National Registry of Health Establishments (CNES - Cadastro Nacional de Estabelecimentos de Saúde).

The CNES (http://cnes.datasus.gov.br/) is a Ministry of Health database that manages the health care network and provides information on the functioning of health services throughout the country. The search was performed on January 27, 2015, totaling 198 hospitals registered as teaching hospitals in Brazil; however, duplications were found, and therefore the sample ultimately consisted of the CCIHs of 193 hospitals.

\section{Data COllection}

The physical addresses and telephone numbers of the technicians and/or nurses of the CCIH of the university hospitals were initially located. From there, telephone contact was established, explaining the objectives of the study and requesting an electronic address to send a copy of the ethical approval, the invitation letter, the link to access the Informed Consent Form (ICF) and the online questionnaire. Topics within the questionnaire related to: the socio-demographic characterization of the participants; the practice or not of an active search during hospitalization; and PDS of SSI cases. They were given ninety days after the invitation email to complete the questionnaire.

\section{DATA ANALYSIS AND PROCESSING}

Data analysis was performed using the Statistical Package Social Sciences (SPSS) software, version 20.0. The results were presented according to frequency distributions and descriptive statistical measures such as arithmetic mean, standard deviation, median, minimum and maximum values for the quantitative variables. The associations were tested by Fisher's exact test, WilcoxonMann-Whitney test and Pearson's Chi-squared test. The $\mathrm{p}$-value was set at 0.05 .

\section{ETHICAL ASPECTS}

The project was approved by the Research Ethics Committee of the Nursing School of the Universidade de São Paulo, under number 1.075.047/2015, in compliance with the Resolution 466 of 2012, of the National Health Council.

\section{RESULTS}

Of the 193 teaching hospitals in Brazil, eight (4.1\%) institutions declined to participate in the study, stating that they did not perform PDS, while 36 (18.6\%) institutions did not respond to the telephone requests. Finally, out of the 149 hospital institutions contacted by telephone who received the questionnaires sent by the researchers, only $25(16.8 \%)$ of these institutions responded to the survey (Figure 1).

All of the respondents were nurses, females with ages mainly between 31 and 40 years (mean: $38.95 \pm 9.41$ ) and up to 10 years of work experience in the field $(19 ; 76 \%)$ (Table 1).

In addition to nurses, other professionals who make up the $\mathrm{CCIH}$ are: physicians $(25 ; 29 \%)$, nursing technicians and auxiliaries $(11,12.7 \%)$, pharmacists $(11 ; 12.7 \%)$ and in $14(16.2 \%)$ cases other professionals such as administrators, microbiologists and engineers. The CCIH teams were composed by $3.2 \pm 1.22$ professionals.

The majority $(15 ; 60 \%)$ of the answers obtained were from institutions located in the southeastern region of Brazil, which were publicly funded (64\%), had fewer than 200 hospital beds (mean: $316.56 \pm 220.44$ ), and performed up to 400 surgical procedures monthly (mean: 504.5 \pm 428.8 ) (Table 2). 


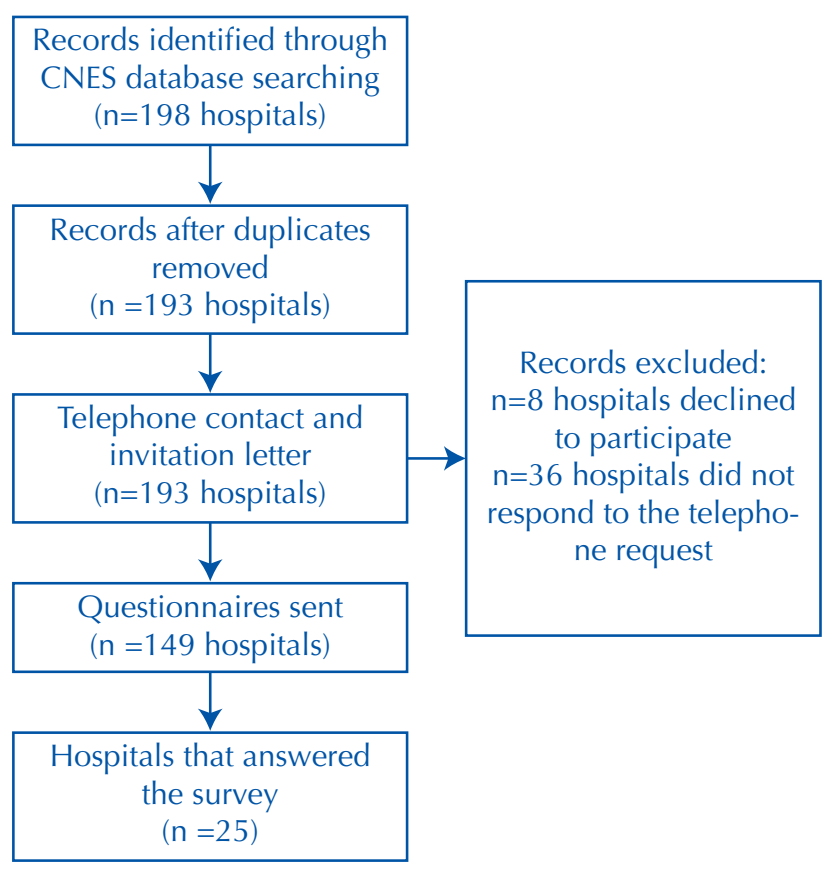

Figure 1 - Flowchart of survey data collection- São Paulo, SP, Brazil, 2016.

Table 1 - Socio-demographic and professional data of nurses who work in the CCIH of university hospitals - São Paulo, SP, Brazil, 2016.

\begin{tabular}{|c|c|c|c|}
\hline Variable & & $\mathbf{N}$ & $\%$ \\
\hline \multirow{2}{*}{ Gender } & Female & 25 & 100 \\
\hline & Male & - & - \\
\hline \multirow{5}{*}{ Age (years) } & 21 to 30 & 3 & 12 \\
\hline & 31 to 40 & 11 & 44 \\
\hline & 41 to 50 & 8 & 32 \\
\hline & 51 to 70 & 2 & 8 \\
\hline & Losses & 1 & 4 \\
\hline \multirow{5}{*}{$\begin{array}{l}\text { Additional } \\
\text { training }\end{array}$} & $\begin{array}{l}\text { Specialization in HAI } \\
\text { Control }^{\mathrm{a}}\end{array}$ & 17 & 68 \\
\hline & Specialization in other areas & 6 & 24 \\
\hline & $\begin{array}{c}\text { Master's degree in HAI } \\
\text { Control }\end{array}$ & 5 & 20 \\
\hline & $\begin{array}{c}\text { Master's degree in other } \\
\text { areas }\end{array}$ & 4 & 16 \\
\hline & Doctorate in other areas & 1 & 1 \\
\hline \multirow{3}{*}{$\begin{array}{l}\text { Working time at the } \\
\text { institution (years) }\end{array}$} & 1 to 10 & 14 & 56 \\
\hline & 11 to 20 & 6 & 24 \\
\hline & 21 to 40 & 5 & 20 \\
\hline \multirow{3}{*}{$\begin{array}{l}\text { Working time at the } \\
\text { CCIH }^{\mathrm{b}} \text { (years) }\end{array}$} & 1 to 10 & 19 & 76 \\
\hline & 11 to 20 & 5 & 20 \\
\hline & 21 to 30 & 1 & 4 \\
\hline \multirow{2}{*}{$\begin{array}{l}\text { Other activities while } \\
\text { working at the CCIH }\end{array}$} & Yes & 2 & 8 \\
\hline & No & 23 & 92 \\
\hline
\end{tabular}

a HAI: Health care-associated infections

b $\mathrm{CCIH}$ : Comissão de Controle de Infecção Hospitalar (Hospital Infection Control Committee)

Note $(n=25)$
Table 2 - Profile of Brazilian teaching hospitals - São Paulo, SP, Brazil, 2016.

\begin{tabular}{|c|c|c|c|}
\hline Variable & & $\mathrm{N}$ & $\%$ \\
\hline \multirow{5}{*}{ Region } & Southeast & 15 & 60 \\
\hline & South & 5 & 20 \\
\hline & Midwest & 4 & 16 \\
\hline & Northeast & 1 & 4 \\
\hline & North & 0 & 0 \\
\hline \multirow{2}{*}{ Funding } & Public & 16 & 64 \\
\hline & Mixed & 9 & 36 \\
\hline \multirow{4}{*}{ Beds } & Less than 200 & 13 & 52 \\
\hline & 201 to 300 & 6 & 24 \\
\hline & 301 to 600 & 3 & 12 \\
\hline & More than 601 & 3 & 12 \\
\hline \multirow{4}{*}{ Adult ICU ${ }^{\mathrm{a}}$ beds } & None & 1 & 4 \\
\hline & Less than 10 & 7 & 28 \\
\hline & 11 to 25 & 15 & 60 \\
\hline & More than 26 & 2 & 8 \\
\hline \multirow{3}{*}{$\begin{array}{l}\text { Pediatric/neonatal } \\
\text { ICU beds }\end{array}$} & None & 3 & 12 \\
\hline & Less than 10 & 6 & 24 \\
\hline & 11 to 25 & 16 & 64 \\
\hline \multirow{7}{*}{ Performs/attends } & Urology/Gynecology & 24 & 8.8 \\
\hline & General surgery & 23 & 8.4 \\
\hline & Pediatrics & 21 & 7.7 \\
\hline & Hemodialysis & 19 & 38.7 \\
\hline & Oncology & 18 & 36.7 \\
\hline & Transplants & 9 & 18.3 \\
\hline & Not applicable & 3 & 6.1 \\
\hline \multirow{12}{*}{$\begin{array}{l}\text { Surgical Specialties } \\
\text { offered }\end{array}$} & Thorax and Lung & 21 & 7.7 \\
\hline & Gastro-surgery & 21 & 7.7 \\
\hline & Vascular & 21 & 7.7 \\
\hline & Head and neck & 20 & 7.3 \\
\hline & Neurosurgery & 19 & 6.9 \\
\hline & Ophthalmology & 18 & 6.6 \\
\hline & Ears, nose, throat & 18 & 6.6 \\
\hline & Orthopedics & 17 & 6.2 \\
\hline & Oncology & 14 & 5.1 \\
\hline & Trauma & 13 & 4.7 \\
\hline & Cardiac & 12 & 4.3 \\
\hline & Others & 11 & 4 \\
\hline \multirow{5}{*}{$\begin{array}{l}\text { Approximate } \\
\text { average of surgeries } \\
\text { per month }\end{array}$} & Losses & 3 & 12 \\
\hline & Less than 200 & 6 & 24 \\
\hline & 201 to 400 & 7 & 28 \\
\hline & 401 to 600 & 4 & 16 \\
\hline & More than 601 & 5 & 20 \\
\hline \multirow{4}{*}{$\begin{array}{l}\text { Approximate } \\
\text { average of clean } \\
\text { surgeries per month }\end{array}$} & Losses & 6 & 24 \\
\hline & Less than 200 & 11 & 44 \\
\hline & 201 to 400 & 5 & 20 \\
\hline & More than 401 & 3 & 12 \\
\hline
\end{tabular}

aCU: Intensive Care Unit

Note: $(n=25)$ 
In relation to the surveillance of SSI during hospitalization, 24 (96\%) of the responding institutions reported that it was performed with a balance between SSI surveillance among clean surgery $(11 ; 45.8 \%)$, and clean and clean-contaminated surgery $(11 ; 45.8 \%)$ (Table 3$)$.

The main method of SSI surveillance was active searching $(22 ; 29.3 \%)$, followed by the culture of microbiology laboratories $(19 ; 25.3 \%)$, in which the collected information is mainly destined to the Epidemiological Surveillance Center (CVE - Centro de Vigilância Epidemiológica) with 19 (26.7\%) of the responses (Table 3).

Table 3 - Active Search for infection of a surgical site during hospitalization in Brazilian university hospitals - São Paulo, SP, Brazil, 2016.

\begin{tabular}{|c|c|c|c|}
\hline Variable & & $\mathbf{N}$ & $\%$ \\
\hline \multirow{2}{*}{$\begin{array}{l}\text { Performs active SSI } \\
\text { search }\end{array}$} & Yes & 24 & 96 \\
\hline & No & 1 & 4 \\
\hline \multirow{3}{*}{ Wound class } & Clean & 11 & 45.8 \\
\hline & $\begin{array}{l}\text { Clean and clean- } \\
\text { contaminated }\end{array}$ & 11 & 45.8 \\
\hline & Others & 2 & 8.3 \\
\hline \multirow{2}{*}{$\begin{array}{l}\text { Collection of } \\
\text { SSI }^{a} \text { data }\end{array}$} & Some surgeries & 12 & 50 \\
\hline & All surgeries & 12 & 50 \\
\hline \multirow{5}{*}{$\begin{array}{l}\text { SSI Surveillance } \\
\text { Method }\end{array}$} & Active Search & 22 & 29.3 \\
\hline & $\begin{array}{l}\text { Cultures from microbiology } \\
\text { laboratories }\end{array}$ & 19 & 25.3 \\
\hline & $\begin{array}{l}\text { Retrospective search } \\
\text { (medical records) }\end{array}$ & 14 & 18.6 \\
\hline & $\begin{array}{l}\text { Communication or } \\
\text { notification from the medical } \\
\text { or surgical team }\end{array}$ & 11 & 14.6 \\
\hline & Others & 9 & 12 \\
\hline \multirow{5}{*}{$\begin{array}{l}\text { Professional } \\
\text { responsible }\end{array}$} & Nurse & 23 & 60.5 \\
\hline & Physician & 6 & 15.7 \\
\hline & Nursing Technician & 4 & 10.5 \\
\hline & Nursing assistant & 3 & 7.8 \\
\hline & Others & 2 & 5.2 \\
\hline \multirow{3}{*}{$\begin{array}{l}\text { Definitions used for } \\
\text { diagnostics }\end{array}$} & $\mathrm{ANVISA}^{\mathrm{b}}$ & 18 & 51.4 \\
\hline & $\mathrm{CDC}^{\mathrm{c}}$ & 13 & 37.1 \\
\hline & From the hospital & 4 & 11.4 \\
\hline \multirow{5}{*}{$\begin{array}{l}\text { Destination of } \\
\text { the information } \\
\text { collected }\end{array}$} & $\mathrm{CVE}^{\mathrm{d}}$ & 19 & 26.7 \\
\hline & Inpatient units & 18 & 25.3 \\
\hline & $\mathrm{CClH}^{\mathrm{e}}$ & 15 & 21.1 \\
\hline & Surgeons & 14 & 19.7 \\
\hline & Others & 5 & 7 \\
\hline
\end{tabular}

aSSI: surgical site infection; ${ }^{\mathrm{b}}$ ANVISA: Agência Nacional de Vigilância Sanitária (National Health Surveillance Agency); ${ }^{c} C D C$ : Centers for Disease Control and Prevention; ${ }^{d} C V E$ : Centro de Vigilância Epidemiológica (Epidemiological Surveillance Center); ${ }^{~} \mathrm{CCIH}$ : Comissão de Controle de Infecção Hospitalar (Hospital Infection Control Committee).

Note: $(n=25)$
In relation to PDS, 21 (84\%) of the respondents confirmed carrying it out, especially those classified as clean and clean-contaminated $(7 ; 33.3 \%)$ and those classified as clean (6; 28.5\%). The main method of PDS was by telephone (15; $42.8 \%)$, followed by outpatient return $(12 ; 34.2 \%)$, in which the collected information is mainly destined to the CVE with 20 (27.4\%) of the responses (Table 4). The association of PDS strategies occurred in mean $1.28( \pm 0.90)$, ranging between 1 and 4 .

The post-discharge search usually occurs within 30 days (12; $57.1 \%) ; 100 \%$ of the institutions stated that they performed ambulatory care after discharge and that outpatient return time takes place according to the specialist's decision $(13 ; 52 \%)$ (Table 4).

The main professional responsible for the PDS is the nurse $(22 ; 73.3 \%)$, based on recommendations of the National Health Surveillance Agency (ANVISA) (20; $55.5 \%$ ) (Table 4).

Table 4 - Post-discharge surveillance of surgical site infection in Brazilian teaching hospitals - São Paulo, SP, Brazil, 2016.

\begin{tabular}{|c|c|c|c|}
\hline Variable & & $\mathrm{N}$ & $\%$ \\
\hline \multirow{2}{*}{ Performs PDS ${ }^{a}$} & Yes & 21 & 84 \\
\hline & No & 4 & 16 \\
\hline \multirow{4}{*}{ PDS method } & Telephone & 15 & 42.8 \\
\hline & Outpatient return & 12 & 34.2 \\
\hline & E-mail & 1 & 2.8 \\
\hline & Others & 7 & 20 \\
\hline \multirow{4}{*}{$\begin{array}{l}\text { Type of surgery } \\
\text { chosen for PDS }\end{array}$} & $\begin{array}{l}\text { Clean and clean- } \\
\text { contaminated }\end{array}$ & 7 & 33.3 \\
\hline & Clean & 6 & 28.5 \\
\hline & All types of surgeries & 4 & 19 \\
\hline & Others & 4 & 19 \\
\hline \multirow{4}{*}{$\begin{array}{l}\text { Time for post- } \\
\text { discharge search }\end{array}$} & 7 days & 2 & 9.5 \\
\hline & 15 days & 4 & 19 \\
\hline & 30 days & 12 & 57.1 \\
\hline & Others & 3 & 14.2 \\
\hline \multirow{2}{*}{$\begin{array}{l}\text { Post-discharge } \\
\text { outpatient care }\end{array}$} & Yes & 25 & 100 \\
\hline & No & - & - \\
\hline \multirow{4}{*}{ Outpatient return } & $\begin{array}{l}\text { Depending on the } \\
\text { specialization }\end{array}$ & 13 & 52 \\
\hline & 7 days & 6 & 24 \\
\hline & 15 days & 5 & 20 \\
\hline & Not sure & 1 & 4 \\
\hline \multirow{4}{*}{$\begin{array}{l}\text { Professional } \\
\text { responsible }\end{array}$} & Nurse & 22 & 73.3 \\
\hline & Nursing Technician & 4 & 13.3 \\
\hline & Nursing assistant & 2 & 6.6 \\
\hline & Physician & 2 & 6.6 \\
\hline \multirow{4}{*}{$\begin{array}{l}\text { Definitions used for } \\
\text { diagnostics }\end{array}$} & $\mathrm{ANVISA}^{\mathrm{b}}$ & 20 & 55.5 \\
\hline & $\mathrm{CDC}^{\mathrm{c}}$ & 12 & 33.3 \\
\hline & From the hospital & 3 & 8.3 \\
\hline & Others & 1 & 2.7 \\
\hline \multirow{5}{*}{$\begin{array}{l}\text { Destination of } \\
\text { the collected } \\
\text { information }\end{array}$} & $\mathrm{CVE}^{\mathrm{d}}$ & 20 & 27.4 \\
\hline & Inpatient units & 18 & 24.6 \\
\hline & Surgeons & 17 & 23.2 \\
\hline & $\mathrm{CCIH}^{\mathrm{e}}$ & 17 & 23.2 \\
\hline & Others & 1 & 1.3 \\
\hline
\end{tabular}

aPDS: Post-discharge surveillance; ${ }^{\mathrm{b}}$ ANVISA: Agência Nacional de Vigilância Sanitária (National Health Surveillance Agency); 'CDC: Centers for Disease Control and Prevention; ${ }^{\mathrm{C}} \mathrm{CVE}$ : Centro de Vigilância Epidemiológica (Epidemiological Surveillance Center); ${ }^{\mathrm{e}} \mathrm{CCIH}$ : Comissão de Controle de Infecção Hospitalar (Hospital Infection Control Committee).

Note: $(n=25)$ 
There was no statistical difference between to perform PDS and number of hospital beds ( $\mathrm{p}=0.107)$; hospital funding $(p=0.624)$; country region $(p=0.076)$; number of clean surgeries/month $(\mathrm{p}=0.692)$; and the number of CCIH professionals $(p=0.470)$.

\section{DISCUSSION}

The results of this study point to the nurse as a key member of the team in conducting SSI surveillance actions during and after hospitalization. Regarding the surveillance actions during hospitalization, the active search and microbiological culture analysis were highlighted. The PDS model most used by the institutions in this study was telephone contact, followed by outpatient return.

However, one result of the study which deserves attention was the low response rate to the survey, which may be due (among other reasons) to the fact that these institutions do not have PDS systems of their patients. This highlights the need for a more in-depth discussion about the need and benefits of PDS actions, especially when the scientific literature produced in several countries reveals that most SSI cases present in the post-discharge period, regardless of the degree of investment in health and/or economic development of the country ${ }^{(4-10)}$.

Thus, failure to perform PDS leads to a significant underreporting of cases, as the SSI rates among clean and clean-contaminated surgery indicated in the scientific literature detected using PDS (although very variable) reach up to $94.8 \%{ }^{(5-10)}$. Moreover, the implementation of PDS programs allows the identification of a significant number of deep SSI cases and patient readmission to different health institutions other than those where the surgical procedure was originally performed ${ }^{(5-10)}$.

Several surveillance methods currently available are not feasible in hospitals with lower financial resources, where data extraction from hospitalization records is a challenge and the electronic linkage of these hospital records to those of basic care is almost impossible ${ }^{(11)}$.

Thus, the World Health Organization (2016) recognizes the various challenges related to PDS influenced by the economic development of the countries. Countries with low income present important follow-up losses; therefore, it is recommended that institutions invest in enabling patients to recognize signs and symptoms that may be indicative of SSI and to implement PDS through telephone calls. Countries with greater economic development also experience difficulties associated with implementing PDS measures; however, these are more related to identifying microorganisms or the completeness/quality of clinical data collection ${ }^{(4)}$.

It is noted that the results of studies on PDS actions carried out in several countries show different rates, and are often higher than those reported by the competent local government agencies ${ }^{(6-7,12)}$. These differences can be explained by the different methodologies and definitions used by the services, but mainly because hospitals with higher rates may have PDS programs that actually function ${ }^{(12)}$.

With regard to this latter aspect, the lack of robust scientific evidence to demonstrate which PDS methods are indeed effective must be considered, which combined with a lack of adequate standardization concepts for PDS compromises the quality of this observation ${ }^{(13)}$.

In addition, it is often observed that patients who develop SSI do not necessarily return to the original institutions, which favors lower estimates among these hospitals that do not implement adequate PDS methods, or those that only use the readmission data to estimate their SSI post-discharge rates ${ }^{(13-14)}$.

Surveillance for SSI is an important preventive measure, considering that when surveillance data is properly acquired, analyzed and implemented, it has important implications in planning patient care methods, in the audit of surgical results $^{(15-16)}$, and in contributing to reduce infection rates.

Therefore, current adequate implementation of PDS and consistent programs in health services (preferably) following national regulatory guidelines will allow for generating more reliable estimates, favoring comparisons between services, in addition to stimulating programs to improve surgical care by collaborating to determine points to be optimized, thus leading to quality care provided to patients.

However, the lack of national regulatory measures that established the actions needed and the adequate follow-up, weaken the creation of robust monitoring systems. It is also perceived that the existing national guidelines are still too subtle to demonstrate the importance that the PDS should occupy within Brazilian SSI control.

Thus, this study points out important aspects to be considered in addition to the establishment of more effective regulatory mechanisms. There is a need for the development and dissemination of scientific studies aimed at PDS at the national level, which portray the reality experienced in Brazilian services, the dissemination of successful PDS strategies, the development of tools that are cost-effective; and optimize the performance and reliability of PDS data.

The PDS is often considered an onerous measure for hospital institutions, particularly in low and middle income countries $^{(13-14)}$, so it is becoming increasingly more relevant the engagement of the patients during their care in and out of the hospital ${ }^{(17)}$, generating a paradigm shift and also affecting the health professional education, leading to the recognition that surgical hospital care is not finalized at the patients discharge.

A limitation of this study may be related to the decision to send the questionnaires by email, a measure adopted to address the extensive geographic dimensions of Brazil; however, this fact may have interfered in the response rate, despite the efforts made regarding telephone confirmations of the e-mail addresses and clarifications of several questions relating to the research.

\section{CONCLUSION}

According to this study, nurses are the main professional group responsible for SSI surveillance actions during hospitalization and after discharge. In relation to SSI surveillance during hospitalization, the active search and cultures from microbiology laboratories were highlighted. The most commonly used PDS method was telephone contact and outpatient returns. Detected SSI notifications are sent to the CVE.

It is surmised that SSI surveillance among teaching hospitals in Brazil remains low. 


\section{RESUMO}

Objetivo: Compreender a realidade da vigilância pós-alta hospitalar das infecções do sítio cirúrgico em hospitais universitários brasileiros. Método: Estudo transversal conduzido por envio de um questionário on-line para enfermeiros do Comitê de Controle de Infecção Hospitalar dos hospitais universitários brasileiros registrados no Cadastro Nacional de Estabelecimentos de Saúde. Resultados: Dos 193 hospitais universitários do Brasil, oito declinaram participar, já que não fazem vigilância pós-alta, e 36 não responderam. Vinte e cinco dos 149 hospitais restantes forneceram respostas detalhadas e 96\% das instituições que responderam realizavam vigilância das infecções do sítio cirúrgico durante a hospitalização; a busca ativa (29,3\%) foi o método principal, ao passo que $84 \%$ relataram realizar vigilância pós-alta basicamente por telefone $(42,8 \%)$. Ambas as ações de vigilância tiveram os enfermeiros como os principais profissionais responsáveis. Conclusão: Os enfermeiros têm um papel proeminente nas ações de identificação/ triagem das infecções do sítio cirúrgico, e a busca ativa durante a hospitalização aliada à vigilância por telefone pós-alta foram os métodos preferenciais.

\section{DESCRITORES}

Infecção da Ferida Cirúrgica; Alta do Paciente; Vigilância; Cuidados de Enfermagem; Hospitais de Ensino.

\section{RESUMEN}

Objetivo: Comprender la realidad de la vigilancia post alta hospitalaria de las infecciones del sitio quirúrgico en hospitales universitarios brasileños. Método: Estudio transversal realizado mediante el envío de un cuestionario en línea a los enfermeros del Comité de Control de Infección Hospitalaria de los hospitales universitarios brasileños inscritos en el Registro Nacional de Establecimientos Sanitarios. Resultados: De los 193 hospitales universitarios de Brasil, ocho declinaron participar, puesto que no hacen vigilancia post alta, y 36 no respondieron. Veinticinco de los 149 hospitales restantes proporcionaron respuestas detalladas y el 96\% de los centros que respondieron realizaban vigilancia de las infecciones del sitio quirúrgico durante la hospitalización; la búsqueda activa (29,3\%) fue el método principal, mientras que el $84 \%$ relataron llevar a cabo vigilancia post alta básicamente por teléfono $(42,8 \%)$. Ambas acciones de vigilancia tuvieron a los enfermeros como los principales profesionales responsables. Conclusión: Los enfermeros juegan un rol prominente en las acciones de identificación/cribado de las infecciones del sitio quirúrgico, y la búsqueda activa durante la hospitalización aliada a la vigilancia por teléfono fueron los métodos preferentes.

\section{DESCRIPTORES}

Infección de la Herida Quirúrgica; Alta del Paciente; Vigilancia; Atención de Enfermería; Hospitales de Enseñanza.

\section{REFERENCES}

1. Gibson A, Tevis S, Kennedy G. Readmission after delayed diagnosis of surgical site infection: a focus on prevention using the American College of Surgeons National Surgical Quality Improvement Program. Am J Surg [Internet]. 2014 [cited 2018 June 14];207(6):832-9. Available from: https://www.ncbi.nlm.nih.gov/pmc/articles/PMC4811594/

2. Morris MS, Deierhoi RJ, Richman JS, Altom LK, Hawn MT. The relationship between timing of surgical complications and hospital readmission. JAMA Surg. 2014;149(4):348-54. DOI: 10.1001/jamasurg.2013.4064

3. Guerra J, Guichon C, Isnard M, So S, Chan S, Couraud S, et al. Active prospective surveillance study with post-discharge surveillance of surgical site infections in Cambodia. J Infect Public Health. 2015;8(3):298-301. DOI: 10.1016/j.jiph.2014.09.007

4. World Health Organization. Global Guidelines for the Prevention of Surgical Site Infection [Internet]. Geneva: WHO; 2016 [cited 2018 June 26]. Available from: http://www.who.int/gpsc/ssi-prevention-guidelines/en/

5. Løwer HL, Dale H, Eriksen HM, Aavitsland P, Skjeldestad FE. Surgical site infections after hip arthroplasty in Norway, 2005-2011: influence of duration and intensity of postdischarge surveillance. Am J Infect Control. 2015;43(4):323-8. DOI: 10.1016/j.ajic.2014.12.013

6. Staszewicz W, Eisenring MC, Bettschart V, Harbarth S, Troillet N. Thirteen years of surgical site infection surveillance in Swiss hospitals. J Hosp Infect. 2014;88(1):40-7. DOI: 10.1016/j.jhin.2014.06.003

7. Limòn E, Shaw E, Badia JM, Piriz M, Escofet R, Gudiol F, et al. Post-discharge surgical site infections after uncomplicated elective colorectal surgery: impact and risk factors. The experience of the VINCat Program. J Hosp Infect. 2014;86(2):127-32. DOI: 10.1016/j.jhin.2013.11.004

8. De Nardo P, Gentilotti E, Nguhuni B, Vairo F, Chaula Z, Nicastri E, et al. Post-caesarean section surgical site infections at a Tanzanian tertiary hospital: a prospective observational study. J Hosp Infect. 2016;93(4):355-9. DOI: 10.1016/j.jhin.2016.02.021

9. Woelber E, Schrick EJ, Gessner BD, Evans HL. Proportion of surgical infections occuring after hospital discharge: a systematic review. Surg Infect (Larchmt). 2016;17(5):510-9. DOI: 10.1089/sur.2015.241

10. Guerra J, Isnard M, Guichon C. Postdischarge surveillance of surgical site infections using telephone calls and a follow-up card in a resource-limited setting. J Hosp Infect. 2017;96(1):16-9. DOI: 10.1016/j.jhin.2017.02.019

11. Aiken AM, Wanyoro AK, Mwangi J, Mulingwa P, Wanjohi J, Njoroge J, et al. Evaluation of surveillance for surgical site infections in Thika Hospital, Kenya. J Hosp Infect [Internet]. 2013 [cited 2018 June 14];83(2):140-5. Available from: https://www.ncbi.nlm.nih.gov/pmc/ articles/PMC3580288/

12. Tanner J, Padley W, Kiernan M, Leaper D, Norrie P, Baggott R. A benchmark too far: findings from a national survey of surgical site infection surveillance. J Hosp Infect. 2013;83(2):87-91. DOI: 10.1016/j.jhin.2012.11.010

13. Leaper D, Tanner J, Kiernan M. Surveillance of surgical site infection: more accurate definitions and intensive recording needed. J Hosp Infect. 2013;83(2):83-6. DOI: 10.1016/j.jhin.2012.11.013.

14. Yokoe DS, Avery TR, Platt R, Huang SS. Reporting surgical site infections following total hip and knee arthroplasty: impact of limiting surveillance to the operative hospital. Clin Infect Dis. 2013;57(9):1282-8. DOI: 10.1093/cid/cit516

15. Różańska A, Jarynowski A, Kopeć-Godlewska K, Wójkowska-Mach J, Misiewska-Kaczur A, Lech M, et al. Does surgical site infection after Caesarean section in Polish hospitals reflect high-quality patient care or poor postdischarge surveillance? Results from a 3-year multicenter study. Am J Infect Control. 2018;46(1):20-5. DOI: 10.1016/j.ajic.2017.07.025 
16. Woodfield JC, Jamil W, Sagar PM. Incidence and significance of postoperative complications occurring between discharge and 30 days: a prospective cohort study. J Surg Res. 2016;206(1):77-82. DOI: 10.1016/j.jss.2016.06.073

17. Wilson J. Preventing surgical site infection: The challenge of 'getting it right first time'. J Infect Prev [Internet]. 2017 [cited 2018 June 26] ;18(4):164-6. Available from: https://www.ncbi.nlm.nih.gov/pmc/articles/PMC5496694/

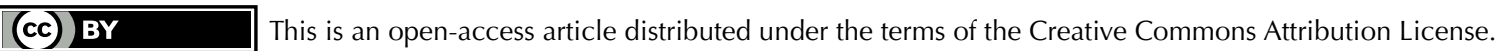

